\title{
When the EU takes the field. Innovative forms of regulatory enforcement in the fisheries sector
}

Citation for published version (APA):

Eliantonio, M., \& Cacciatore, F. (2022). When the EU takes the field. Innovative forms of regulatory enforcement in the fisheries sector. Journal of European Integration, 44(4), 551-568. https://doi.org/10.1080/07036337.2021.1910253

Document status and date:

Published: 19/05/2022

DOI:

10.1080/07036337.2021.1910253

Document Version:

Publisher's PDF, also known as Version of record

Document license:

Taverne

Please check the document version of this publication:

- A submitted manuscript is the version of the article upon submission and before peer-review. There can be important differences between the submitted version and the official published version of record.

People interested in the research are advised to contact the author for the final version of the publication, or visit the DOI to the publisher's website.

- The final author version and the galley proof are versions of the publication after peer review.

- The final published version features the final layout of the paper including the volume, issue and page numbers.

Link to publication

\footnotetext{
General rights rights.

- You may freely distribute the URL identifying the publication in the public portal. please follow below link for the End User Agreement:

www.umlib.nl/taverne-license

Take down policy

If you believe that this document breaches copyright please contact us at:

repository@maastrichtuniversity.nl

providing details and we will investigate your claim.
}

Copyright and moral rights for the publications made accessible in the public portal are retained by the authors and/or other copyright owners and it is a condition of accessing publications that users recognise and abide by the legal requirements associated with these

- Users may download and print one copy of any publication from the public portal for the purpose of private study or research.

- You may not further distribute the material or use it for any profit-making activity or commercial gain

If the publication is distributed under the terms of Article $25 \mathrm{fa}$ of the Dutch Copyright Act, indicated by the "Taverne" license above, 


\section{Journal of European Integration}

\section{When the EU takes the field. Innovative forms of regulatory enforcement in the fisheries sector}

\section{Mariolina Eliantonio \& Federica Cacciatore}

To cite this article: Mariolina Eliantonio \& Federica Cacciatore (2021): When the EU takes the field. Innovative forms of regulatory enforcement in the fisheries sector, Journal of European Integration, DOI: 10.1080/07036337.2021.1910253

To link to this article: https://doi.org/10.1080/07036337.2021.1910253

\section{Published online: 07 Apr 2021.}

\section{Submit your article to this journal $\longleftarrow$}

山 Article views: 152

Q View related articles

View Crossmark data \lceil 


\title{
When the EU takes the field. Innovative forms of regulatory enforcement in the fisheries sector
}

\author{
Mariolina Eliantonio (iD) and Federica Cacciatore (iD ${ }^{\mathrm{b}}$ \\ aFaculty of Law, Maastricht University, MD Maastricht (NL), Netherlands; 'bepartment of Public Function, \\ Italian Presidency of the Council of Ministers, Rome, Italy
}

\begin{abstract}
One of the main weaknesses of the EU and causes of citizens' disaffection is its alleged scarce effectiveness in achieving its targets among various policy sectors. This, among other reasons, is due to member states' (MS) lack of compliance or uneven implementation performance, which, in turn, results from the traditional share of tasks, according to which the EU institutions adopt policies, while the MS implement them and enforce them. After many and reiterated actions by the EU, aiming to foster better and more complete compliance to EU law through soft measures and incentives to MS, another trend is emerging, by which the EU is gradually taking on direct enforcement competences in a growing number of policy sectors. Moreover, the ways through which the EU is taking the field in the enforcement phase are many and diverse, ranging from direct full enforcement powers to differently shared and networked roles with the MS and the other actors involved. In such evolving governance, a crucial role is played by EU agencies, established ad hoc or attributed new tasks to deal with enforcement issues.

Arguing that such verticalization of the enforcement powers is an expanding trend, we take the fisheries sector as a case study. Among the Common Fisheries Policy, indeed, this phenomenon is already gaining traction and displays a variety of new configurations of powers. We find that verticalized enforcement takes on different shapes, depending on the specific sub-phase of the enforcement process, In addition, we provide insights on how enforcement mechanisms of the Common Fisheries Policy work in practice.
\end{abstract}

\section{KEYWORDS}

Enforcement; CFP; European governance; EFCA; inspections

\section{Introduction}

It is common knowledge among scholars and institutions that one of the main weaknesses of the EU and causes of citizens' disaffection is its alleged scarce effectiveness in achieving its targets among various policy sectors. This, in turn, is due to various reasons, one of which is member states' (MS) lack of compliance or uneven implementation performance within the traditional division of tasks, according to which the EU institutions adopt policies, while the MS implement them and enforce them.

After many and reiterated actions by the EU, aiming to foster better and more complete compliance to EU law through soft measures and incentives to MS, another

CONTACT Federica Cacciatore f.cacciatore@governo.it Department of Public Function, Italian Presidency of the Council of Ministers, Via del Sudario, 4900186 Rome (IT) 
trend is emerging, by which the EU is gradually taking on direct enforcement competences in a growing number of policy sectors. Such trend in the evolving relationships between Member States and the EU, which is involving an increasing number of policy sectors, and that entails an upward shift of the enforcement activities from the national to the supranational level, has been globally referred to as verticalization of enforcement (Scholten 2017; Scholten and Luchtman 2017). Against this background, EU agencies are gaining a crucial role: either they are established ad hoc or are attributed new tasks to deal with enforcement issues. We argue that one of the most important causes for this phenomenon is that the EU is trying to gain more output legitimacy by achieving more policy effectiveness, and, to do this, it is taking the field in increasing policy sectors by directly ensuring their implementation and compliance.

The ways through which the EU is taking the field in the enforcement phase are many and diverse. The literature studying the verticalization of enforcement in the EU has shown that verticalization is not a monolithic phenomenon but rather can take various forms, ranging from granting the EU full enforcement powers (Drake and Smith 2016; Van Rijsbergen and Foster 2017; Scholten 2020) to setting up differently shared and networked roles with the MS and the other actors involved (Van Der Heijden 2016). However, little has been said about the relationship between the broad verticalization process and the specific sub-phases of enforcement. Our main hypothesis is that verticalization may assume different configurations, depending - amongst other - on the specific sub-phase of the enforcement process itself. In order to contribute to a better understanding of this complex phenomenon, we aim to investigate whether different forms of verticalized enforcement can be associated with different sub-phases of the enforcement process (inspections, reporting, data sharing, sanctions, etc.). To this end, we take the European fisheries sector as a case study. In this area, a Common Fisheries Policy (CFP) is in place since the early $80 \mathrm{~s}$. There, the verticalization phenomenon is already in place and displays a variety of new configurations of powers, depending on the enforcement mechanisms at stake (Cacciatore and Eliantonio 2017, 2019a). Through the analysis of the fisheries sector, a part of the more general EU maritime policy, we argue that verticalized enforcement varies in its configuration and degrees, depending on the specific sub-phase of the enforcement process.

Analysing such a specific policy sector as the fisheries in the EU is particularly suited to identify and assess innovative forms of enforcement, for at least four reasons.

First, issues and policies regarding fisheries involve a high number of MS, insofar as currently from $3 \%$ to $5 \%$ of the EU's gross domestic product comes from the fisheries sector, while almost $90 \%$ of foreign trade and about $43 \%$ of intra-EU trade take place via maritime routes (European Commission 2014, 3). Around a hundred of thousands of boats are in operation in Europe, flying the flags of all MS, also non-coastal ones. ${ }^{1}$ Moreover, the EU fishing fleet is very diverse, with vessels ranging from under $6 \mathrm{~m}$ to over 75 (European Commission 2018,10$)$. Such variety also leads to different degrees of implementation and compliance with rules on fisheries.

Second, the fisheries sector is characterized by a huge amount of illegal activity (Klein 2011). It is estimated that every year between eleven and twenty-six million tonnes of fish are caught illegally worldwide, corresponding to at least $15 \%$ of the total catches (European Commission 2018, 8). Since the EU is strongly committed in fighting illegal fishing, which is to be considered a «major threat to global marine resources» (European 
Commission 2018), the CFP comprises the toolbox through which such policy objectives may be pursued; it mostly comprises regulatory tools, which often address technical issues regarding fisheries, typologies of fish stocks to be safeguarded and fishing instruments that can be authorized. Such issues necessarily require targeted regulatory provisions, and a strong commitment in making them effective throughout the EU; therefore, enforcement proves particularly important in such a policy, and innovative ways of achieving it are more likely to be explored than in other fields.

Third, another peculiar feature of the CFP that makes it fit for an analysis of how regulatory implementation and enforcement work is its cross-country impact, given that where actions (and possible infringements) take place may not correspond to where their actors belong, or to where those actions could be accounted for, investigated, and

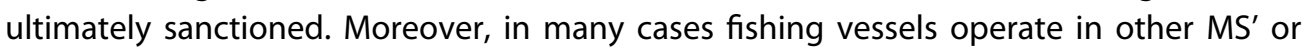
in third countries' waters, so that relationships between countries are common and crucial to manage them. Just think of the impact on fisheries that 'Brexit' will have in the near future, according to which the UK and the EU will have to find different alternative means to manage fisheries relations when it comes to UK fishing operations involving third countries and the other way around. It is no coincidence that the lively debate preceding the 'Brexit' referendum of 23 June 2016 has greatly involved the issue of fisheries, both politically and institutionally (Huggins et al. 2019; Tingle 2016; Cacciatore and Eliantonio 2017, 171).

Finally, overfishing, namely, the practice of fishing more fish than is biologically sustainable, is one of the most serious threats to the aquatic ecosystem and a challenging commitment for the EU, especially in light of the much variation in the degree of overfishing across the EU countries (Kirkpatrick 2020).

The remainder of the paper is structured as follows. In Section 2 we draw an evolution of the process that led in many policy sectors in the EU to verticalization of the enforcement and define enforcement and its many possible models within the EU policy cycle. In Section 3 we take into account the enforcement mechanisms in the CFP, by illustrating the different sub-phases in which the overall process is divided, add by attributing different forms of enforcement to each sub-phase. Finally, in Section 4 we draw some conclusions and trace some paths for future research.

\section{From the implementation gap to the verticalization of enforcement}

As authoritatively said, Europeanization of enforcement is no longer about coordination between national agencies only, but new models of enforcement in EU are emerging and new ad hoc agencies are increasingly being established (Ottow 2017). In particular, whereas the changes and developments in regulatory governance have been widely investigated - an example is the successful stream of studies on experimentalist governance (Eckert and Börzel 2012; Rangoni and Zeitilin 2020), aiming to detect new forms of cooperation between the involved parties to improve EU regulation - a black box in the knowledge of the mechanisms underlying new forms of EU policymaking is related to its later phases, especially implementation and enforcement. This is also related to the fact that multilevel arenas for interinstitutional cooperation in the EU, so far, have been mostly focused on policy formulation and adoption, leaving to Member States the task to implement them and watch over their effectiveness. This may be regarded as the 
'traditional' division of powers between the EU and the national levels of government, where the EU is attributed regulatory competences, and the national level is competent for the implementation and enforcement sub-phases of the EU policy process, as regulated by the Treaties (Scholten 2017), also due to concerns about national sovereignty (Scholten 2020). The main exception to this scheme has traditionally been competition law, a policy in which the Commission has been attributed, since its inception, direct enforcement powers.

However, in more recent times a new trend is emerging, according to which the traditional governmental scheme within the implementation and enforcement phases is being challenged by new forms of cooperation between different levels of government. In particular, unlike previously, where the involved actors were mainly identified according to the specific phases of the policymaking process, more recently a less formal division of powers may be highlighted, one where all categories of actors may participate in all phases, through various patterns of cooperation and with different degrees of active involvement depending on the policy sector and the policy phase. Within such evolving context, a major change relates to the novel role of EU institutions and actors in implementation and enforcement, formerly the prerogative of Member States (Ottow 2017). Such direct uptake of powers by the EU in later phases of the policymaking is observable in a growing number of policy sectors, and involves both implementation (Migliorati 2020) and enforcement (Scholten and Luchtman 2017).

Against this backdrop, the so-called verticalization of enforcement powers and competences (Scholten 2017; Scholten and Luchtman 2017; Scholten 2020) relates, in particular, to the phenomenon by which EU institutions, either the existing ones or newly ad hoc established agencies, are attributed specific powers and tasks within the enforcement phase of EU legislation, previously the competence of Member States. An example is the European Central Bank's power to impose sanctions to banks and credit institutions within the European Banking Union, which formerly could only be sanctioned by national authorities.

More specifically, the verticalization of enforcement has two main characteristics: a) direct EU tasks and powers may be exerted in different sub-phases in which the enforcement stage is articulated; b) such uptake may be complete, in cases where EU actors are exclusively responsible for them, or variously shared and balanced with the Member States (or other actors), and more or less formalized in relevant EU secondary law provisions.

Such development of the enforcement governance in the EU is an empirical acquaintance, insofar it has been detected and analysed in various policy sectors (Scholten and Luchtman 2017). Nevertheless, it is also theoretically supported by the coexistence of many causal factors, among which the crucial role played by the Commission's strive to self-empowerment, in search of greater policy effectiveness and larger compliance, as previously highlighted.

The effective implementation and application of EU law indeed has long been a matter of concern to the EU, alongside the national parliaments, since it is strictly linked to the question of the EU's legitimacy. Traditionally, EU's so-called output legitimacy has been identified with its capacity to deliver the wanted results (Lindgren and Persson 2010). The dichotomy input vs. output legitimacy was introduced by Scharpf (1999), whereas the former is mostly related to the existence of procedural tools and guarantees for 
democracy, and the latter is mostly referred to the perceived efficiency of its outputs (see also Risse 2006). Given the nature and structure of EU institutions, therefore, their main source of legitimacy is related to their outputs, namely their policies. It follows that a perceived poor policy effectiveness might give way to citizens' dissatisfaction and discomfort with the EU (Mény 2003; Majone 2006). Because a political system's legitimacy is not stable, but it rather requires more or less formalized interventions by the affected institutions (Mény 2003, 252), the European Commission is directly engaged in the quest for more legitimacy. Moreover, it is the primary institution concerned with the enforcement of EU law, in that, as guardian of the Treaties (pursuant to Article 17 TEU), it is attributed the task of ensuring its effective application, mainly through the application of the infringement procedure (Article 258 TFEU) and of the financial sanction (Article 260 TFEU) (Smith 2018). There are three different types of failure to fulfil EU obligations: failure to notify measures transposing a directive; non-conformity or non-compliance, whenever legislation is not in line with the requirements of EU legislation; finally, incorrect or bad application cases, whenever legislation has not been applied properly (Smith 2018).

Its direct involvement in overseeing implementation and enforcement issues has led the Commission to adopt annual tools to monitor and communicate data on the application of EU norms. The main one is the report on Monitoring the application of Union Law (European Commission 2019b), through which data are released with reference both to single policy sectors and single countries. The need to improve policy implementation also with a view to contrast citizens' distrust towards the EU thereby - was indeed evident since the White paper on European governance that the Commission issued in 2001 (European Commission 2001), where it was clearly stated that «[m]ore effective enforcement of Community law is necessary not only for the sake of efficiency of the internal market but also to strengthen the credibility of the Union and its Institutions» (European Commission 2001, 5).

Nevertheless, as the Commission itself points out, infringement procedures «are an option of last resort to achieve» compliance with EU law (European Commission $2019 c$, 2). For this reason, other ways, such as «good cooperation and communication» between the Commission and the MS are boosted and preferred, also through appropriate tools to help the latter transpose, apply and implement EU law correctly and timely. These may be guidance documents, implementation plans, expert groups, explanatory documents, training activities, workshops and so on (European Commission 2019c, 2).

Despite growing attention towards such issues, the implementation deficit, about which much has already been written by different perspectives (for all: Thomann and Zhelyazkova 2017; Mastenbroek 2005; Haverland and Romeijn 2007; Kaeding 2006; Lampinen and Uusikylä 1998), seems to be slightly increasing over the last years, if we look at the trends in complaints and investigations about potential breaches of EU law (Milio 2010; European Commission 2019c, 11).

In addition to the annual report from the Commission, other studies and reports on the implementation deficit both within single policy sectors (to cite some: Bursens 2002; Jensen 2007; Michelsen 2008) ${ }^{2}$ and regarding specific countries (to cite some: Mastenbroek 2003; Borghetto, Franchino, and Giannetti 2006) are not missing.

To cope with such gaps, deemed to be one of the most crucial causes of lack of efficacy and citizens' dissatisfaction, the EU has triggered different changes in governance over 
the last decades, aimed at supplying the policies with more effectiveness and a stronger oversight system. Some of such changes were more of an informal nature, such as the (support for the) creation of specific administrative networks of regulators and enforcers (Mastenbroek and Martinsen 2018); others required more formal decisions, such as the creation of ad hoc agencies and/or authorities, or the attribution to existing ones of specific enforcement tasks (Scholten, Luchtman, and Schmidt 2017). Since 1999, indeed, the number of bodies with enforcement powers has grown from one to eight: within the Commission, the Directorate-General for Competition, the 'Directorate- $F$ ' on food law and the Anti-Fraud Office (OLAF); the European Medicines Agency (EMA); the European Aviation Safety Agency (EASA); the European Fisheries Control Agency (EFCA); the European Securities and Markets Authority (ESMA); the European Central Bank (ECB) (Scholten, Luchtman, and Schmidt 2017, 2-3).

These two major changes (although mostly spanned over time), in conjunction, have brought about that different approach to enforcement, which was mentioned before. Namely, the shift from a model where EU policies are issued at a supranational level and implemented and enforced at national level, implying only an indirect enforcement oversight by the EU institutions, to one where the EU also plays a direct enforcement role, often by means of an authority or an agency.

This is the case with the CFP, where both changes are visible: an ad hoc agency, the EFCA, was formally established to carry out direct enforcement activities, and networks between the involved actors were informally set up to manage new issues in the enforcement of the fisheries rules. As we will see in detail in the following section, the fisheries sector proved to be an appropriate test field for innovative forms of regulatory enforcement, from direct EU involvement to more networked ones.

\subsection{Between direct and shared enforcement. An analytical model}

As will be clarified later, what is peculiar with the CFP, and with mixed administration of EU policies in general (Jans, Prechal, and Widdershoven 2015), is that enforcement (along with regulation) is subdivided between different actors, and powers distribution may change across the specific sub-phase concerned. Powers are therein distributed in different manners and with varying degrees of formalization. Before introducing a more detailed analysis of the enforcement process within the CFP, it is worth providing a definition of the main typologies of enforcement governance, which will then help us analyse how enforcement governance varies according to the single sub-phases.

The first and classical typology of enforcement is the one where no EU involvement is foreseen. In this case, the mentioned traditional distribution of powers is to be found, where the EU issues policies and regulations and MS are responsible for their implementation and enforcement.

A second form of enforcement is where, on the opposite, the EU directly takes on specific enforcement competences, with no intermediation by MS. Although formerly unusual, this direct relationship between the EU and the regulatees is gradually gaining ground. In its most powerful version, direct enforcement results in the possibility for EU institutions to impose sanctions and penalties (e.g. in the financial supervision or in antitrust law); however, also the power to conduct direct inspections by means of EU inspectors, abiding by supranational rules and procedures, is a form of direct enforcement. 
Between no and direct EU involvement, there may be halfway models where distribution of powers is less neat; they may vary in degree of formalization. The main halfway models are shared and networked enforcement. While both are featured by the co-presence of EU and national enforcers, the former (shared enforcement) is characterized by a formalized distribution of powers between the EU and national competent authorities, which always cooperate pursuant to specific legal provisions. The second (networked enforcement) is related to more collaborative forms of enforcement between MS and the EU, which are not always formalized through legal provisions, nor do they always involve an active role for traditional EU institutions or for the agencies (Cacciatore and Eliantonio 2019a, 2). As previous literature has highlighted, these forms of collaborative enforcement aim at overcoming the criticisms to the traditional enforcement models (Van Der Heijden 2016; Scholten 2020), by allocating each specific task to the most suited actor, drawing on the «responsive regulation» strategy (Ayres and Braithwaite 1992). From such perspective, they may also help to overcome the so-called "governance dilemma» (Eberlein and Newman 2008), based on the notion that, while EU involvement is supposed to foster more compliance to EU regulation, MS are never too prone to a formal transfer of their powers.

\section{Direct EU enforcement and beyond: innovative forms of enforcement in the Common Fisheries Policy}

One of the policy sectors where the innovative drive in enforcement was more visible over the last decade was the EU fisheries. This was largely due to the implementation deficit that long featured it - and about which much has been written (among others: DaRocha, Cerviño, and Villasante 2012; Khalilian et al. 2010; Johnson 2008; Symes 2009; Hegland and Raakjær 2008), and whose technical causes were hugely investigated by the specialist literature (Gezelius 2008), and to the - subsequent - evolution of the policy itself. In order to provide a more detailed picture of the topic, we will first briefly describe the evolution of the CFP and then we will focus on the innovation therein when it comes to enforcement.

\subsection{Evolution of the Common Fisheries Policy and the European Fisheries Control Agency: the trend towards verticalized enforcement}

The relevance of marine fisheries and aquaculture for all governments dealing with coastal areas is well known. This is most notably the case with the EU, where 22 out of 27 MS have a coastline and almost half of its population lives in maritime regions (Cacciatore and Eliantonio 2019a, 5ff.; European Commission 2018; European Union 2014). It follows that the EU fishing industry holds a key role worldwide: it is the fourth largest, providing more than six million tonnes yearly and jobs for more than 350.000 workers. ${ }^{3}$ Compliance with the rules aimed at safeguarding maritime resources and environment is therefore essential, both to sustain the ecosystem and to grant a thriving and competitive future to fisheries and the related economic activities.

A first step towards the establishment of a CFP was taken in 1983, whereas through further changes and amendments it was gradually enlarged in scope and made more complex in terms of governance between the EU and the MS involved. ${ }^{4}$ Among the first 
issues addressed by the CFP were rules about areas restricted to fishery, standard fishing gear used and minimum fish sizes. Moreover, since 1983 a fish management scheme was adopted yearly, including the Total Allowable Catches (TACs) agreed by the Fisheries Council.

Nonetheless, the CFP's scarce effectiveness soon emerged as a concern, and quickly MS' responsibilities also became apparent (DaRocha, Cerviño, and Villasante 2012; Gray and Hatchard 2003).

In 2001, therefore, a first major CFP revision, through the adoption of a Green Paper on the future of the Common Fisheries Policy, ${ }^{5}$ led to a more decentralized implementation system, where enforcement powers were to be delegated to the lowest competent administrative level (Eliasen, Hegland, and Raakjær 2015). Accordingly, Council Regulation $2371 / 2002^{6}$ on the conservation and sustainable exploitation of fisheries resources under the Common Fisheries Policy set up stronger and clearer enforcement powers on the part of the MS.

It was against that background that the European Fisheries Control Agency, EFCA (formerly named Community Fisheries Control Agency) was established in 2005, ${ }^{7}$ aiming to «coordinate control and inspection by Member States relating to the control and inspection obligations of the Community». Another such step towards a more verticalized enforcement, putting the agency at the centre of it, was brought in 2009 with the adoption of Council Regulation 1224/2009, ${ }^{8}$ establishing an EU-wide control system for ensuring compliance with the CFP. According to the new framework, EFCA was granted both direct enforcement powers (see infra) and an enhanced role in fostering cooperation between MS regarding those enforcement activities upon which they remain competent (Cacciatore and Eliantonio 2019a).

Between 2012 and 2013 another major change took place, following an agreement between the Council and the European Parliament aimed at conferring more effectiveness to the CFP enforcement. This was achieved mainly through a governance shift towards marine regions, in the idea that providing them with a more central role would have helped improve their performance (Salomon, Markus, and Dross 2014). The amended CFP came into force on 1 January $2014 .^{9}$

\subsection{Unpacking the enforcement process within the CFP}

Within the framework of a regulatory state, as the one in which the EU can be located, enforcement may be seen as a specific phase of the regulatory policy process, that takes place after the implementation phase has (not) exerted its effects and before the policy dismantling/validating/amending phase. It may either be located within the late implementation phase, as a sub-phase therein (cf. Winter 2006; Short 2019, 3) - indeed, the perspective by which we address this topic. Enforcement is therefore understood as

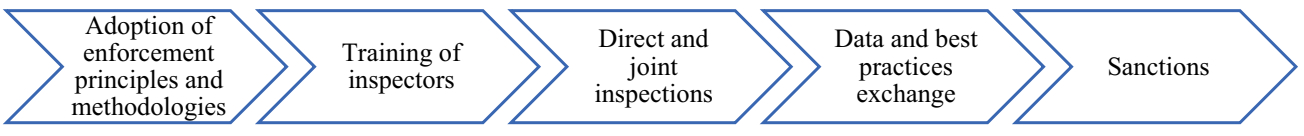

Figure 1. Sub-phases of the CFP implementation process. 
a common cross-sectoral sub-phase of almost every regulatory policy, which is complementary and functional for their correct implementation.

In turn, enforcement may be considered as a specific process, composed itself by smaller single sub-phases, or activities. Depending on the specific regulatory policy, it may differ according to the rules and praxes in force.

With regard to the CFP, taking into account its specific mission to manage European fishing fleets and to preserve fish stocks, through promotion of the cooperation between the involved authorities, we may identify some specific tasks within the enforcement phase, which can be summarized into the following five activities (as illustrated in Figure 1): a) adoption of enforcement principles and methodologies; b) training of inspectors; c) direct inspections and participation in national inspections; d) data and best practices exchange; e) sanctions.

Adoption of general enforcement principles and methodologies. These are set up at the European level, upon collaboration with the MS. The Commission has established specific roles and principles with Regulation 1224/2009. The main tools are the Specific Control and Inspection Programmes (SCIPs), adopted by the Commission in concert with the concerned MS (art. 95), and the Joint Deployment Plans (JDPs).

According to the Regulation, the MS concerned must adopt the necessary measures to ensure the implementation of the SCIPs. Fisheries control and inspection activities undertaken by MS should then be carried out in accordance with common criteria, priorities, principles and procedures, to be adopted by means of the JDPs. In other words, whereas the Commission establishes the SCIPs in the CFP framework in cooperation with MS, EFCA is attributed the key task of implementing them through the adoption of JDPs, whose content is laid down in art. 11 of Regulation 473/2019. ${ }^{10}$ JDPs provide general criteria and reference indicators for the three main phases of the control and inspection activities to be conducted by the MS: planning, implementation and assessment, while it is in general not responsible for the design of CFP's enforcement policies as regards sanctioning.

Training of inspectors. In the overall framework of the CFP, at the supranational level EFCA is also endowed with training functions for national inspectors. Regulation 473/2019 confers it the role to coordinate inspector training and the exchange of experience between MS (art. 3(g)) and to carry out and promote research and development activities in that field (art. 3(f)). Moreover, art. 7 lists some specific tasks within EFCA's overall assistance role: the establishment and development of a core curriculum for the training of the instructors of the fisheries inspectorate of the MS and of the EU inspectors and provision of «additional training courses and seminars to those officials and other personnel involved in control and inspection activities». EFCA may also, upon request from the Commission or MS, develop common inspection methodologies and procedures and draw up joint operational procedures in relation to joint control and inspection activities undertaken by two or more MS (art. 7(g)); it may also issue manuals on harmonised standards of inspections (art. 20).

Inspections. Direct inspections are probably the most evident and typical (though not the only one, nor necessarily the most important) of all enforcement-related activities, one through which the authority and power to make regulations work is expressed most patently. Within the CFP, on-site inspections can be conducted either by national inspectors, which is the most likely case, or by «Union inspectors», namely by inspectors acting 
on behalf of the EU. According to art. 4 of Regulation 1224/2009, Union inspectors are «officials of a Member State or the Commission or the body designated by it, whose names are contained in [a specific] list». Therefore, the general competence to adopt appropriate measures and ensure control, inspection and enforcement activities within the CFP is attributed to the MS (art. 5 of Regulation 1224/2009), ${ }^{11}$ whereas in specific circumstances inspections can be carried out by Union inspectors. Namely, art. 79 of the same Regulation establishes that the Commission issue a list of Union inspectors, who may conduct inspections in EU waters and on EU fishing vessels outside EU waters, either in the framework of SCIPs or international fisheries control programmes, where the EU is under an obligation to provide for controls. Therefore, Union inspectors may either be EFCA or Commission staff members. Regarding EFCA officials acting as Union inspectors, according to art. 19 of Regulation 473/2019, they may carry out direct inspections in international waters on behalf of the EU, in accordance with the mentioned art. 79 of the same regulation.

Moreover, within the CFP Commission officials and EFCA members might as well take part in joint inspections with national inspectors, under, respectively, art. 98 of Regulation 1224/2009 and art. 5(2) of Regulation 473/2019. In addition, EFCA's members are competent to assist MS in reporting information related to the inspections to the Commission and third parties (art. 3, Regulation 473/2019). Therefore, EFCA's members may participate in joint inspections conducted according to the JDPs, playing a coordinating role, $^{12}$ and no formal boundaries are set between the «assisting» role of EFCA and what is carried out directly by the national inspectors. To this aim, EFCA may also be requested to take up coordinating tasks in those fisheries or fishing areas which are not subject to a SCIP: two or more MS may agree to ask for such coordination of their means of control and inspection, according to criteria and priorities previously agreed between the countries concerned (art. 16, Regulation 473/2019). ${ }^{13}$

Finally, pursuant to art. 97 of Regulation 1224/2009, inspections may be conducted also by Commission officials, both on fishing vessels and on the premises of businesses, "to the same extent and under the same conditions as officials of the Member State in which the verification and inspection take place», but with «no powers going beyond those of national inspectors» and without any police or enforcement powers; moreover, whenever there is a reasonable doubt that infringements to the CFP have been committed, Commission officials may carry out autonomous inspections even without the presence of national authorities ${ }^{14}$ (art. 99).

Besides conducting direct inspections, according to art. 98 of Regulation 1224, Commission staff members may also take part in joint inspections carried out by the involved MS according to specific JDPs «[w]herever it is deemed necessary by the Commission", and establishing, together with them, a mutually acceptable verification programme. This is also the case with EFCA members entitled to «organise the operational coordination of control and inspection» by MS, pursuant to art. 5(2) of Regulation 473/ 2019.

Data and best practices exchange. Another activity carried out within the enforcement of the CFP relates to a number of systems aimed at helping the involved actors in sharing data on fisheries activities (Princen, Siderius, and Villasante 2020). A central role in such respect is played by EFCA, which not only provides for the formal coordination of MS' enforcement activities but also supplies them with shared databases, systems and 
technologies to view, collect, share and (re)use data on fisheries-related activities (cf. Cacciatore and Eliantonio 2019a). Such a network is set up to help conduct inspections and sanctioning operations in support of the JDPs activities. The main tool is represented by the Fisheries Information System (FIS), ${ }^{15}$ an integrated system composed of the EFCA electronic reporting system (ERS), the EFCA electronic inspection report system (EIR), the vessel monitoring system (VMS) and Fishnet, a web-based system providing for a virtual office-like environment to support the transfer of information through various means (voice, email, instant messaging, videoconferences). Regarding the VMS, it is one of the most important tools for the exchange of data, through a satellite-based monitoring system providing data to the fisheries authorities on the location, course and speed of vessels. Its legal basis is represented by art. 9 of Regulation 1224/2009, which provides that all coastal MS set up mutually compatible systems in order to allow for the exchange of data between countries and for the Commission's oversight on compliance to the rules. These data, collected through the VMS and managed by the Commission, allow the monitoring of fishing vessels in real-time, in particular for control purposes. The data are mainly managed by the MS' fisheries monitoring centres, but in specific cases they are provided to the Commission services. ${ }^{16}$ Moreover, EFCA provides MS with the EIR Systems Software as Service (SaaS), to use as their own domestic system.

Sanctions. Once the above operations are completed, and in case of ascertained infringements, the sanctioning activities are, to date, exclusively the competence of MS, regardless of the level (supranational, national, mixed) at which the inspection was carried out. Nevertheless, within the overall framework of enforcement principles and methodologies, some criteria on sanctioning activities have been set up EU-wide. In particular, the Commission has introduced as from 2012 an EU point system for serious fisheries infringements, to which MS have to conform, in order to ensure that fishing rules are applied in the same way everywhere, and to harmonise the way infringements are sanctioned. ${ }^{17}$ This system does not introduce new sanctions nor does it interfere in any way with the discretionary power of the national authorities.

According to art. 87 of Regulation 1224/2009, MS are entitled to take all appropriate measures as well in cases in which infringements were detected - in waters under their sovereignty or jurisdiction, or on vessels flying their flag - by Union inspectors.

\subsection{Varieties of enforcement in the CFP}

Having illustrated the main enforcement forms involved in the CFP, let us now apply the scheme introduced before, so as to analyse how they vary across the sub-phases.

Adoption of general enforcement principles and methodologies. As said, the general principles and methodologies for the enforcement of CFP are set at the EU level, upon collaboration of the MS. More specifically, the actors involved are the Commission and the concerned MS for the adoption of specific SCIPs, and EFCA with, again, the concerned MS for the adoption of the subsequent JDPs, through which control and inspection criteria are set up (Cacciatore and Eliantonio 2017, 172, 2019b, 128). Therefore, insofar as the Commission issues general principles, EFCA sets out criteria and methodologies ${ }^{18}$ and MS must comply with them through specific multiannual fisheries enforcement programmes, drafted according to the former, this specific sub-phase of the CFP enforcement is characterized by a mechanism of shared enforcement. 
Training of inspectors. Drawing on the activities previously illustrated, activities undertaken by national and Union inspectors are based on training and experience exchanged via the key role of EFCA, mandated to build core curricula to this aim. EFCA may also, on request from the Commission or $\mathrm{MS}$, develop common inspection methodologies and procedures and draw up joint operational procedures in relation to joint control and inspection activities undertaken by two or more Member States (art. 7(g) of Regulation 473/2019), or issue manuals on harmonised standards of inspections (art. 20). Therefore, in this sub-phase we may identify a mechanism of networked enforcement, because the interaction between the agency and MS is based on mostly informal relations and activities, which may also rise in number anytime MS deem it useful to involve EFCA to improve inspectors' training.

Inspections. This is the field where the variety of innovative forms of enforcement shows up most visibly, insofar as all of the four pinpointed types are present, depending on what kind of inspections are being conducted.

a) First, according to Regulation 1224/2009, as said, inspection activities within the CFP are the competence of MS, and this standard procedure entails no EU involvement (as usual in the past decades throughout the EU policy fields).

b) Second, as mentioned, the EU may conduct direct inspections via:

- its Union inspectors, who may either be Commission (or MS) officials or EFCA staff members. They are mandated, under EU legislation, to carry out inspection and surveillance of fishing activities in European Union waters, outside the zones under the sovereignty of MS (Commission officials), and in international waters (EFCA officials);

- Commission officials, who, pursuant to mentioned art. 97 of Regulation 1224/2009, may «carry out verifications and inspections [...] and shall have access to all information and documents needed to exercise their responsibilities, to the same extent and under the same conditions as officials of the Member State in which the verification and inspection take place».

c) Third, the duty to conduct inspections may also be a mechanism of networked enforcement between the MS concerned and the Commission, whenever Commission officials or EFCA members take part or assist in the abovementioned joint inspections.

Data and best practices exchange. As mentioned, a relevant sub-phase of the CFP enforcement process lies in data sharing and the exchange of best practices among the involved actors. Against this background, EFCA provides for formalised coordination of the MS' enforcement activities and supplies them with shared databases and systems, to

Table 1. Forms of EU involvement in the enforcement of the CFP.

\begin{tabular}{|c|c|c|c|c|c|}
\hline & Adoption of principles and & Training of & & Data and best practices & \\
\hline & & & Inspections & exchange & Sanctions \\
\hline $\begin{array}{l}\text { No EU } \\
\text { enforcement }\end{array}$ & & & MS & & MS \\
\hline $\begin{array}{l}\text { Direct } \\
\quad \text { Enforcement }\end{array}$ & & & $\begin{array}{c}\text { EFCA } \\
\text { EC }\end{array}$ & & \\
\hline $\begin{array}{l}\text { Shared } \\
\text { Enforcement }\end{array}$ & $\begin{array}{c}\text { EFCA } \\
\text { EC } \\
\text { MS }\end{array}$ & & & & \\
\hline $\begin{array}{l}\text { Networked } \\
\text { Enforcement }\end{array}$ & & $\begin{array}{c}\text { EFCA } \\
\text { MS }\end{array}$ & $\begin{array}{c}\text { EFCA } \\
\text { EC } \\
\text { MS }\end{array}$ & $\begin{array}{c}\text { EFCA } \\
\text { MS }\end{array}$ & \\
\hline
\end{tabular}


help them view, collect, share and use data on fisheries. Such networked activity was set up and is increasingly being improved in order to help MS carrying out inspections - and sanctioning activities - more effectively and more evenly throughout the EU (Cacciatore and Eliantonio 2019a, 7). This one is, therefore, a clear instance of networked enforcement.

Sanctions. So far, as said, all the sanctioning powers are still exclusively the competence of MS, regardless of the institutional level to which the inspectors who detected the infringements belong. In this case, therefore, no EU involvement is foreseen as regards the final decisions to be taken towards the regulatees.

The above mechanisms offer a varied picture of the possible forms of enforcement that may be experienced throughout the wider enforcement process of CFP, from monitoring to detection to the final decisions. Table 1 summarizes them.

In addition to the traditional distribution of powers, which is still available within the CFP (MS manage both inspecting and sanctioning activities) growing instances of verticalized enforcement are visible, and in some sub-phases they are the only possible forms of enforcement. In the core sub-phase of onsite inspections, in fact, also due to the very mission of the EFCA, originally established to coordinate supervision and control, experimentation of innovative and multiplayer forms of enforcement has given way to a coexistence of such typologies.

Moreover, the (co-)existence of different forms of enforcement does not appear to be related to the typology of actors at stake: in the policy sector under scrutiny, fisheries, the three main categories of actors involved in enforcement (the EU institutions, the national authorities and, if applicable, an ad hoc agency) are almost evenly distributed among most of the sub-phases of the enforcement process, except for the sanctioning phase.

\section{Conclusions}

Verticalization of enforcement has proven to be a trend in various policy fields throughout the EU, and, as the present work demonstrates, the fisheries policy, which are a key policy sector for the overall EU activities and legitimacy, as illustrated in our introduction, is no exception to that.

We therefore contribute to the growing studies aiming to analyse the new trends in regulatory enforcement and thus link them to the more general evolution of the EU policy making. More specifically, we aimed at further specifying the notion of verticalization of enforcement, by showing that the phenomenon of verticalization comes in various forms, embodying different relationships between the EU and national actors. By taking the fisheries sector as a case study (a crucial yet under-researched area), we found out that the specific form of verticalization may change depending on the specific sub-phases of the enforcement process, as it may assume the form of direct, a shared or a networked enforcement between the involved parties, and in specific sub-phases it may also lack completely.

If we look at the evolution of other policy sectors, and take into account the changes the CFP itself has been experiencing throughout the years, the trend toward a more verticalized enforcement is likely to be confirmed, if not enhanced, in the future. Moreover, it has proved to be a field for governance experimentalism, given the variety of models in place along the enforcement process itself, from no to exclusive EU involvement, via varying degrees of multilevel cooperation arrangements. 
Secondly, the study may prove useful for those, scholars and practitioners, interested in the evolution of the fisheries sector, both from a legal and a more empirical viewpoint.

Nevertheless, a more exhaustive comprehension of the verticalization phenomenon calls for further research, either within single policy sectors, where other relevant instances are already being observed (Scholten and Luchtman 2017), or through much needed comparative and cross-sectoral studies, able to seek and compare conditions and factors affecting it. More research will as well be welcome to understand, among the possible implications that the new trend may have, its impact on the functioning of democratic mechanisms, above all on accountability (Scholten and Luchtman 2017), which is one of the main dimensions of democratic quality (Diamond and Morlino 2005) and specifically the EU's (Schmitter 2003).

In this respect, it is important to consider that these new forms of enforcement may cast some questions as regards the existence (and effectiveness) of corresponding judicial and political accountability mechanisms, whose objective is to legitimate the enforcement activities of the CFP. This holds apparently true first of all for the cases of shared and networked enforcement, which are based on blurred boundaries between different levels' competences. Indeed, previous research has already highlighted the existence of gaps in both judicial and political enforcement with reference to shared and networked (Cacciatore and Eliantonio 2017, 2019a, 2019b, 2020) enforcement mechanisms within the CFP, that are only to a limited extent counterbalanced by the existence of mechanisms of financial accountability. Further research should be devoted to testing empirically whether gaps of judicial or political accountability have arisen in practice and compare the experience of the enforcement of the fisheries policy with other 'verticalised' EU policy areas.

\section{Notes}

1. Except for Luxembourg, whose total catches were deemed non-relevant, in 2010 all the other twenty-seven MS have recorded own catches, although some (e.g. Malta, Slovakia, Cyprus, Slovenia, Austria) with very percentages out of the total (European Commission 2014, 5). It is worth highlighting, nonetheless, that three countries (Spain, Denmark, and France) account for almost half of the EU's total catches.

2. This is the case with environmental policies, where implementation deficit is a long-standing concern (Jordan 1999; European Commission 2019a).

3. For more information, see the EU dedicated website: https://ec.europa.eu/jrc/en/researchtopic/fisheries-and-aquaculture.

4. For a detailed analysis of the evolution of the CFP since the beginning, see Laursen (2020).

5. Commission of the European Communities, Green Paper on the Future of the Common Fisheries Policy, COM(2001) 135 final, Brussels, 20 March 2001.

6. Council Regulation (EC) No. 2371/2002 of 20 December 2002, on the conservation and sustainable exploitation of fisheries resources under the Common Fisheries Policy.

7. Council Regulation (EC) No. 768/2005 of 26 April 2005 establishing a Community Fisheries Control Agency and amending Regulation (EEC) No 2847/93 establishing a control system applicable to the common fisheries policy.

8. Council Regulation (EC) 1224/2009 establishing a Community control system for ensuring compliance with the rules of the common fisheries policy.

9. More information is available at the dedicated EU website: https://ec.europa.eu/fisheries/reform.

10. Regulation (EU) 2019/473 of the European Parliament and of the Council of 19 March 2019 on the European Fisheries Control Agency (codification). There are four ongoing JDPs: 
Mediterranean and Eastern Atlantic (adopted in 2014 and involving nine countries), Baltic Sea, North Sea (both operating since 2007 and both involving eight countries) and Western Waters (established in 2012 and concerning twelve countries).

11. General provisions about CFP inspections are laid down in Title VII of Regulation 1224.

12. For some empirical data on this activity, see EFCA (2019).

13. An example is the recent operational plan named «Black Sea», in force since 2012, to provide specific assistance to Bulgaria and Romania for joint inspection and control activities of turbot fisheries in the Black Sea (see https://www.efca.europa.eu/en/content/other-coordination. See also EFCA (2019: 19)).

14. Nevertheless, pursuant to art. 101, they must inform MS concerned of the preliminary findings of verifications and of autonomous inspections within one day after they have taken place.

15. More information is available at www.efca.europa.eu/en/content/efca-fisheries-informationsystem.

16. See www.efca.europa.eu/en/content/data-and-systems-fisheries-activities. See also the Commission's dedicated website at http://ec.europa.eu/fisheries/cfp/control/technologies/ vms_en.

17. See https://ec.europa.eu/fisheries/cfp/control/infringements_sanctions_en.

18. Which is further implemented in a specific Multiannual Work Programme, adopted every three years and amended annually. See https://www.efca.europa.eu/en/content/multiann ual-work-programme-2019-2020-and-annual-work-programme-2019 for the latest version.

\section{Acknowledgments}

This article is a result of a common undertaking. However, section 2 can be directly attributed to Mariolina Eliantonio; section 3 can be directly attributed to Federica Cacciatore; finally, sections 1 and 4 contain common reflections. Federica Cacciatore's views expressed in this article are personal and do not reflect those of the Italian Presidency of the Council of ministers.

\section{Disclosure statement}

No potential conflict of interest was reported by the authors.

\section{ORCID}

Mariolina Eliantonio (D) http://orcid.org/0000-0002-6736-0647

Federica Cacciatore (ID) http://orcid.org/0000-0003-2094-0625

\section{References}

Ayres, I., and J. Braithwaite. 1992. Responsive Regulation. Transcending the Deregulation Debate. Oxford: Oxford University Press.

Borghetto, E., F. Franchino, and D. Giannetti. 2006. "Complying with the Transposition Deadlines of EU Directives. Evidence from Italy." Rivista Italiana di Politiche Pubbliche 1 (1): 7-38.

Bursens, P. 2002. "Why Denmark and Belgium Have Different Implementation Records: On Transposition Laggards and Leaders in the EU." Scandinavian Political Studies 25 (2): 173-195. doi:10.1111/1467-9477.00068.

Cacciatore, F., and M. Eliantonio. 2017. Fishing in Troubled Waters? Shared Enforcement of the Common Fisheries Policy and Accountability Gaps. In "Law Enforcement by EU Authorities. Implications for Political and Judicial Accountability ${ }_{\text {"', }}$ edited by, Scholten and Luchtman, 168-194. Cheltenham: Edward Elgar. 
Cacciatore, F., and M. Eliantonio. 2020. "Quis Custodiet Ipsos Custodes? Assessing the Systems of Controls of the European Fisheries Control Agency's Inspecting Powers." In Controlling EU Agencies: The Rule of Law in a Multi-jurisdictional Legal Order, edited by M. Scholten and A. Brenninkmeijer, 215-233. Cheltenham: Edward Elgar.

Cacciatore, F., and M. Eliantonio. 2019a. "Networked Enforcement in the Common Fisheries Policy through Data Sharing: Is There Room Left for Traditional Accountability Paradigms?" European Journal of Risk Regulation 10 (3): 522-537. doi:10.1017/err.2019.26.

Cacciatore, F., and M. Eliantonio. 2019b. "Enforcement condiviso in contesti multilivello. Italia e Unione Europea nella Politica comune della pesca." Mercato concorrenza regole 21 (1): 121-144.

DaRocha, J.-M., S. Cerviño, and S. Villasante. 2012. "The Common Fisheries Policy: An Enforcement Problem." Marine Policy 36 (6): 1309-1314. doi:10.1016/j.marpol.2012.02.025.

Diamond, L., and L. Morlino, eds. 2005. Assessing the Quality of Democracy. Baltimore: Johns Hopkins University Press.

Drake, S., and M. Smith, eds. 2016. New Directions in the Effective Enforcement of EU Law and Policy. Cheltenham: Edward Elgar.

Eberlein, B., and A. L. Newman. 2008. "Escaping the International Governance Dilemma? Incorporated Transgovernmental Networks in the European Union." Governance 21 (1): 25-52. doi:10.1111/j.1468-0491.2007.00384.x.

Eckert, S., and T. A. Börzel. 2012. "Experimentalist Governance: An Introduction." Regulation \& Governance 6 (3): 371-377. doi:10.1111/j.1748-5991.2012.01163.x.

EFCA (2019), Annual Report 2018, Vigo: European Fisheries Control Agency.

Eliasen, S. Q., T. J. Hegland, and J. Raakjær. 2015. "Decentralising: The Implementation of Regionalization and Co-management under the Post-2013 Common Fisheries Policy." Marine Policy 62: 224-232. doi:10.1016/j.marpol.2015.09.022.

European Commission (2001), European Governance. A White Paper, COM(2001) 428 final, Brussels, 25 July 2001.

European Commission. 2014. The European Union Explained: Maritime Affairs and Fisheries. Luxembourg: Publications Office of the European Union.

European Commission. 2018. Facts and Figures on the Common Fisheries Policy. Basic Statistical Data - 2018 Edition. Luxembourg: Publications Office of the European Union.

European Commission. 2019a. Study: The Costs of Not Implementing EU Environmental Law. Final Report. Luxembourg: Publications Office of the European Union.

European Commission. 2019b. Monitoring the Application of Union Law. 2018 Annual Report. Luxembourg: Publications Office of the European Union.

European Commission (2019c), Monitoring the Application of Union Law. 2018 Annual Report - Part l: general statistical overview, Luxembourg: Publications Office of the European Union.

European Union. 2014. Maritime Affairs and Fisheries. Luxembourg: Publications Office of the European Union.

Gezelius, S. S. 2008. "The Problem of Implementing Policies for Sustainable Fisheries." In Making Fisheries Management Work. Implementation of Policies for Sustainable Fishing, edited by S. S. Gezelius and J. Raakjær, 1-25. New York: Springer.

Gray, T., and J. Hatchard. 2003. "The 2002 Reform of the Common Fisheries Policy's System of Governance - Rhetoric or Reality?" Marine Policy 27 (6): 545-554. doi:10.1016/S0308-597X(03)00066-6.

Haverland, M., and M. Romeijn. 2007. "Do Member States Make European Policies Work? Analysing the EU Transposition Deficit." Public Administration 85 (3): 757-778. doi:10.1111/j.14679299.2007.00670.x.

Hegland, T. J., and J. Raakjær. 2008. "Recovery Plans and the Balancing of Fishing Capacity and Fishing Possibilities: Path Dependence in the Common Fisheries Policy." In Making Fisheries Management Work. Implementation of Policies for Sustainable Fishing, edited by S. S. Gezelius and J. Raakjær, 131-159. New York: Springer.

Huggins, C., J. Connolly, C. McAngus, and A. Van Der Zwet. 2019. "Brexit and the Future of UK Fisheries Governance: Learning Lessons from Iceland, Norway and the Faroe Islands." Contemporary Social Science 14 (2): 327-340. doi:10.1080/21582041.2018.1516296. 
Jans, J. H., S. Prechal, and R. J. G. M. Widdershoven, eds. 2015. Europeanisation of Public Law. 2nd ed. Groningen: Europa Law Publishing.

Jensen, C. B. 2007. "Implementing Europe: A Question of Oversight." European Union Politics 8 (4): 451-477. doi:10.1177/1465116507082810.

Johnson, C. 2008. "Fisheries Enforcement in European Community Waters since 2002 Developments in Non-Flag Enforcement." The International Journal of Marine and Coastal Law 23 (2): 249-270. doi:10.1163/092735208X272210.

Jordan, A. 1999. "The Implementation of EU Environmental Policy; A Policy Problem without A Political Solution?" Environment and Planning C: Politics and Space 17 (1): 69-90. doi:10.1068/c170069.

Kaeding, M. 2006. "Determinants of Transposition Delay in the European Union." Journal of Public Policy 26 (3): 229-253. doi:10.1017/S0143814X06000547.

Khalilian, S., R. Froese, A. Proelss, and T. Requate. 2010. “Designed for Failure: A Critique of the Common Fisheries Policy of the European Union." Marine Policy 34 (6): 1178-1182. doi:10.1016/j. marpol.2010.04.001.

Kirkpatrick, A. 2020. "Examining the Impact of Institutions on Common Pool Resource Problems: The EU's Common Fisheries Policy." Journal of European Integration 42 (2): 247-262. doi:10.1080/ 07036337.2019.1658752.

Klein, N. 2011. Maritime Security and the Law of the Sea. Oxford: Oxford University Press.

Lampinen, R., and P. Uusikylä. 1998. "Implementation Deficit - Why Member States Do Not Comply with EU Directives?" Scandinavian Political Studies 21 (3): 231-249. doi:10.1111/j.1467-9477.1998.tb00014.x. Laursen, F. 2020. The Development of the EU as a Sea-Policy Actor. Cheltenham: Edward Elgar.

Lindgren, K.-O., and T. Persson. 2010. "Input and Output Legitimacy: Synergy or Trade-off? Empirical Evidence from an EU Survey." Journal of European Public Policy 17 (4): 449-467. doi:10.1080/ 13501761003673591.

Majone, G. 2006. "The Common Sense of European Integration." Journal of European Public Policy 13 (5): 607-626. doi:10.1080/13501760600808212.

Mastenbroek, E. 2003. "Surviving the Deadline: The Transposition of EU Directives in the Netherlands." European Union Politics 4 (4): 371-395. doi:10.1177/146511650344001.

Mastenbroek, E. 2005. "EU Compliance: Still a 'Black Hole'?" Journal of European Public Policy 12 (6): 1103-1120. doi:10.1080/13501760500270869.

Mastenbroek, E., and D. S. Martinsen. 2018. "Filling the Gap in the European Administrative Space: The Role of Administrative Networks in EU Implementation and Enforcement." Journal of European Public Policy 25 (3): 422-435. doi:10.1080/13501763.2017.1298147.

Mény, Y. 2003. "From Popular Dissatisfaction to Populism: Democracy, Constitutionalism, and Corruption." In Governing Europe, edited by G. Hayward and A. Menon, 250-263. New York: Oxford University Press.

Michelsen, J. 2008. “A Europeanization Deficit? The Impact of EU Organic Agriculture Regulations on New Member States." Journal of European Public Policy 15 (1): 117-134. doi:10.1080/ 13501760701702256.

Migliorati, M. 2020. "Where Does Implementation Lie? Assessing the Determinants of Delegation and Discretion in Post-Maastricht European Union" Journal of Public Policy 1-22. advance online publication. doi: 10.1017/S0143814X20000100.

Milio, S. 2010. From Policy to Implementation in the European Union: The Challenge of a Multi-level Governance System. London: I.B. Tauris \& .

Ottow, A. 2017. Foreword. In "Law Enforcement by EU Authorities. Implications for Political and Judicial Accountability, edited by M. Scholten and M. Luchtman, Cheltenham: Edward Elgar.

Princen, S., K. Siderius, and S. Villasante. 2020. "Information Processing in the European Union's Common Fisheries Policy" Journal of Public Policy 1-21. advance online publication. doi: 10.1017/ S0143814X20000124.

Rangoni, B., and J. Zeitilin. 2020. "Is Experimentalist Governance Self-Limiting or Self-Reinforcing? Strategic Uncertainty and Recursive Rulemaking in European Union Electricity Regulation." Regulation \& Governance. advance online publication. 10.1111/rego.12309.

Risse, T. 2006. "Transnational Governance and Legitimacy." In Governance and Democracy, edited by A. Benz and Y. Papadopoulos, 179-199. London: Routledge. 
Salomon, M., T. Markus, and M. Dross. 2014. "Masterstroke or Paper Tiger - The Reform of the EU's Common Fisheries Policy." Marine Policy 47: 76-84. doi:10.1016/j.marpol.2014.02.001.

Scharpf, F. W. 1999. Governing in Europe: Effective and Democratic? Oxford: Oxford University Press. Schmitter, P. C. 2003. "Democracy in Europe and Europe's Democratization." Journal of Democracy 14 (4): 71-85. doi:10.1353/jod.2003.0087.

Scholten, M. 2017. "'Mind the Trend! Enforcement of EU Law Has Been Moving to 'Brussels"." Journal of European Public Policy 24 (9): 1348-1366. doi:10.1080/13501763.2017.1314538.

Scholten, M., M. Luchtman, and E. Schmidt. 2017. The Proliferation of EU Enforcement Authorities: A New Development in Law Enforcement in the EU. In "Law Enforcement by eu Authorities: Implications for Political and Judicial Accountability "', edited by M. Scholten and M. Luchtman, Cheltenham: Edward Elgar.

Scholten, M. 2020. "EU (Shared) Law Enforcement: Who Does What and How?" In EU Law Enforcement. The Evolution of Sanctioning Powers, edited by S. Montaldo, F. Costamagna, and A. Miglio. (pp. 7-24). London: Routledge, forthcoming.

Scholten, M., and M. Luchtman, eds. 2017. Law Enforcement by EU Authorities. Implications for Political and Judicial Accountability. Cheltenham: Edward Elgar.

Short, J. L. 2019. "The Politics of Regulatory Enforcement and Compliance: Theorizing and Operationalizing Political Influences." In Regulation \& Governance. advance online publication. 1-33. doi:10.1111/rego.12291.

Smith, M. 2018. Challenges in the Implementation of EU Law at National Level. European Parliament Briefing Requested by the JURI committee. Luxembourg: Publications Office of the European Union.

Symes, D. 2009. "Reform of the European Union's Common Fisheries Policy: Making Fisheries Management Work." Fisheries Research 99 (2): 99-102. doi:10.1016/j.fishres.2009.06.012.

Thomann, E., and A. Zhelyazkova. 2017. "Moving beyond (Non-)compliance: The Customization of European Union Policies in 27 Countries." Journal of European Public Policy 24 (9): 1269-1288. doi:10.1080/13501763.2017.1314536.

Tingle, R. 2016. "Freedom for Fisheries?" In Breaking up Is Hard to Do. Britain and Europe's Dysfunctional Relationship, edited by P. Minford and J. R. Shackleton (pp. 184-208). London: Institute of Economic Affairs.

Van Der Heijden, J. 2016. The Long, but Promising, Road from Deterrence to Networked Enforcement. In New Directions in the Effective Enforcement of EU Law and Policy,edited by, S. Drake, 77-104. Cheltenham: Edward Elgar.

Van Rijsbergen, M., and J. Foster. 2017. Rating' ESMA's Accountability: 'AAA' Status. In "Law Enforcement by eu Authorities: Implications for Political and Judicial Accountability ${ }_{\text {II }}$ edited by M. Scholten and M. Luchtman, 53-81. Cheltenham: Edward Elgar.

Winter, S. C. 2006. "Implementation." In Handbook of Public Policy, edited by B. G. Peters and J. Pierre, 151-166. London: Sage. 